\title{
Húgyúti kórokozók spektrumának és antibiotikum-rezisztenciájának változása osztályunkon 2004 és 2017 között
}

\author{
Magyar András dr. , Dobák András dr.2, Bálint Péter dr.', \\ Vinodh Kumar Adithyaa Arthanareeswaran dr. ${ }^{3}$, Nagy Károly dr.?, \\ Póth Sándor dr.1, Bata Anikó dr.1, Tenke Péter dr.1, Köves Béla dr.1 \\ 'Jahn Ferenc Dél-pesti Kórház és Rendelőintézet, Urológiai osztály, Budapest (osztályvezető: Tenke Péter dr.) \\ ${ }^{2}$ Corden International, Budapest \\ ${ }^{3}$ Lipcsei Egyetem, Urológiai Klinika, Németország (igazgató: Jens-Uwe Stolzenburg dr.)
}

\author{
Levelezési cím: \\ Dr. Magyar András \\ 1076 Budapest, Thököly út 21. III/28 \\ E-mail: magyara@gmail.com \\ Tel.: +36 31 783-9686
}

\section{ÖSSZEFOGLALÁS}

Bevezetés: A húgyúti fertőzések empirikus kezelése során elengedhetetlen a helyi rezisztenciaviszonyok és az előforduló baktériumok spektrumának ismerete, hiszen ezek földrajzilag és időben is jelentős változatosságot mutathatnak. Célunk az osztályunkon vett vizeletmintákból nyert kórokozók előfordulásának és a leggyakoribb kórokozók antibiotikum-rezisztenciájának évente történő felmérése.

Anyag és módszerek: Osztályunkon minden középsugaras és katéteres vizeletmintából kitenyészett kórokozót és azok antibiotikum-rezisztenciáját rögzítettük 2004 és 2017 között. A bakteriális spektrum és rezisztenciaváltozások statisztikai analízise során a Cochran-Armitage-tesztet alkalmaztuk $(p<0,05)$.

Eredmények: Összesen 3513 vizeletmintában igazolódott szignifikáns mennyiségű kórokozó. A leggyakoribb két kórokozó az Escherichia coli és az Enterococcus faecalis voltak. Az E. coli ciprofloxacin rezisztenciája szignifikánsan nőtt a vizsgálati időszakban, elérte a $25 \%$-ot, míg cefalosporinokkal szemben az E. coli rezisztenciája 20\% alatt maradt.

Következtetések: Súlyos húgyúti fertőzések empirikus kezelésére a fluorokinolonok alkalmazása nem javasolt régiónkban. A cefalosporinok Gram-negatív fertőzések esetén empirikusan biztonsággal alkalmazhatók, viszont kerülendők multirezisztens kórokozók gyanúja esetén. Minden osztály számára javasoljuk a kórokozók spektrumának, illetve érzékenységének évenként történő feltérképezését.

\section{KULCSSZAVAK}

ANTIBIOTIKUM, REZISZTENCIA, UROPATOGÉNEK, BAKTERIÁLIS SPEKTRUM

\section{Changes in the bacteial spectrum and an- tibiotic resistance pattern of uropatho- gens at our department between 2004 and 2017}

\section{SUMMARY}

Objective: Since bacterial antibiotic resistance rates may vary with significant differences between countries and regions, as well as change over time, yearly surveillance of the bacterial spectrum and antibiotic-resistance patterns of locally occurring uropathogens is essential to serve as a basis for empirical treatment of urinary tract infections (UTIS). The objective of our study was to investigate the changes in the bacterial spectrum and the antibiotic resistance rates of uropathogens cultured from urine samples collected at our department.

Material and methods: All urine samples taken at our department, from 2004 to 2017 were retrospectively analyzed. The significance rates of the annual changes were calculated using Cochran-Armitage test $(p<0.05)$.

Results: A total of 3513 urine cultures showed significant presence of pathogens. Escherichia coli and Enterococcus faecalis were the most frequently isolated bacteria. Resistance of $E$. coli to ciprofloxacin has increased significantly, reaching a rate of $25 \%$, while in the case of cephalosporines, resistance of $E$ c coli remained under $20 \%$.

Conclusion: For empirical treatment fluoroquinolones can be no longer recommended in our region. Gram-negative UTIs can be safely treated with cephalosporines, however, they should be avoided if multi-drug resistant bacteria are suspected. Surveillance and monitoring of the bacterial resistance patterns is recommended for all institutions.

\section{KEYWORDS}

ANTIBIOTICS, RESISTANCE, UROPATHOGENS, BACTERIAL SPECTRUM 


\section{Bevezetés}

Az antibiotikumok széles körü alkalmazása a baktériumok rezisztenciájának fokozatos növekedéséhez vezet. Ahhoz, hogy ezt a folyamatot elkerülhessük, illetve lelassítsuk, ezáltal javítva az antibiotikum-kezelések eredményességét, összehangolt nemzetközi stratégiák kidolgozása és széles körű alkalmazása szükséges (1-3).

Egy adott kórképért felelős baktériumok aránya és rezisztenciája időben változhat és földrajzilag is jelentős eltérést mutathat, mivel a helyi antibiotikum-kezelési stratégiák jelentősen befolyásolják a baktériumok antibiotikum-rezisztenciájának alakulását az adott régióban. Ezért alapvetően fontos a helyi rezisztenciaviszonyok időszakos felmérése az urológiai gyakorlatban, mivel ezek ismeretén alapul a húgyúti fertőzések eredményes empirikus kezelése és a sebészeti antibiotikum-profilaxis megtervezése $(4,5)$. Retrospektív vizsgálatunknak az volt a célja, hogy felmérjük a Jahn Ferenc Dél-pesti Kórház és Rendelőintézet Urológiai osztályán vett vizeletmintákból kitenyészett kórokozók előfordulását és antibiotikum-rezisztenciáját, továbbá megvizsgáljuk azok időbeli változását. A régebbi, 2004-2015 közötti eredményeinket előzőleg angol nyelven közöltük (6). Célunk a legfrissebb, 2016-2017-ben felmért adatok közzététele, továbbá a korábbi adataink bemutatása a magyar közönség részére.

\section{Anyag és módszerek}

A Jahn Ferenc Kórház és Rendelőintézet Urológiai Osztályán minden osztályon levett vizelettenyésztés-eredményt rögzítettük a 2004 és 2017 közötti időszakban. Ide tartoztak a középsugaras, katéteres és punkció során vett vizeletminták vizsgálatainak eredményei egyaránt. A mintákat húgyúti fertőzések miatt, illetve a mútéti előkészités részeként adták le a betegek. A bakteriális spektrum- és rezisztenciaváltozásait a CochranArmitage-teszt segítségével vizsgáltuk (szignifikanciaküszöb: $p<0,05)$. Az adatok kielemzése során a következő módszereket és egyszerúsítéseket alkalmaztuk:

1. a rezisztenciaarányok antibiotikumonként kerültek feltüntetésre;

2. a leggyakoribb 5 baktérium antibiotikum-rezisztenciáját és időbeli változását vizsgáltuk, amelyek a minták több mint 5\%-ában jelen voltak;

3. azokban az években, ahol kevés esetszámot észleltünk, az ebből adódó kiugrásokat a legközelebbi éves adatok átlagának kiszámításával küszöböltük ki;

4. a 2010-ig gyúitött adatok korlátozott mennyiségben voltak elérhetőek a számítógépes rendszer akkori hiánya miatt;

5. az adatok hiányosságát a táblázatok celláiban N.M. (nincs meghatározva) jelzéssel láttuk el, amelybe a mikrobiológus döntése alapján nem vizsgált esetek is beletartoznak.

A 2010-ben bevezetett számítógépes rendszer az adatok sokkal részletesebb, pontosabb elemzését tette lehetóvé.

\section{Tenyésztéses módszerek}

A vizeletminták bórsavas tartályokban kerültek átszállításra a mikrobiológiai laboratóriumba.

A baktériumokat 0,01 ml-es kaccsal oltották BD Brilliance UTI agar táptalajra. Az inkubáció $37^{\circ} \mathrm{C}$-on történt, 16-18 órán keresztül, hagyományos termosztátban. Ezt követően a baktériumkolóniák Oxoid-Columbia blood, illetve MacConkey agar táptalajra (Oxoid) kerültek leoltásra. A baktériumok azonosításához BD Phoenix automatizált rendszert (BD Biosciences), vagy ENTEROtest 16 kit-et alkalmaztak (Lachema). A vizelettenyésztés módszertana érdemben nem változott az évek során. 2011-ig a baktériumok antibiotikum-érzékenységét BD Phoenix automatizált rendszer, vagy Mueller-Hinton-agar segítvégével vizsgálták a Clinical and Laboratory Standards Institute (CLSI) irányelvek tükrében (7). 2011-től az European Committee on Antimicrobial Susceptibility Testing (EUCAST) standardoknak megfelelően végezték a vizsgálatokat (8). A MIC-értékek megállapítását BD Phoenix automatizált rendszer, vagy Liofilchem MIC-csíkok segítségével végezték. Az inkubálást követően az izolátumokat az EUCAST MIC-határérték táblázatoknak megfelelően a következő kategóriákba sorolták: érzékeny, mérsékelten érzékeny, rezisztens (8).

\section{Eredmények}

\section{Bakteriális spektrum}

A vizsgált 14 éves időszakban összesen 3513 vizeletmintában igazolódott szignifikáns mennyiségú kórokozó. A kitenyészett baktériumok spektrumának időbeli változása az 1. ábrán látható. A bakteriális spektrumban az évek során érdemi változás nem történt. A vizsgálati időszakban a leggyakoribb kórokozónak az Escherichia coli bizonyult, az esetek 48\%ában tenyészett ki. A legmagasabb értéket 2008-ban érte el,

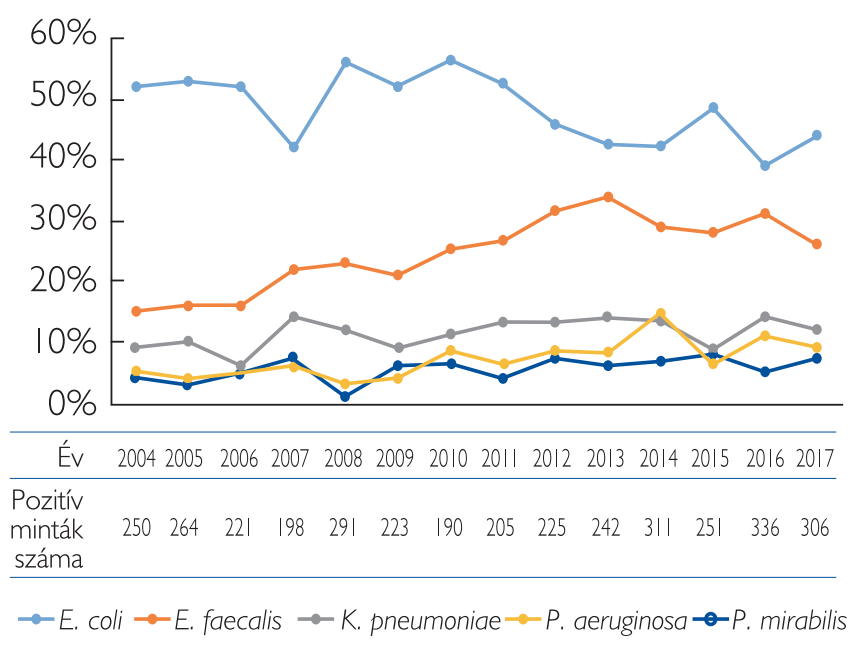

1. ÁBRA: A LEGGYAKORIBB BAKTÉRIUMOK: AZ OSZTÁLYUNKON LEVETT VIZELETMINTÁKBÓL KITENYÉSZETT BAKTÉRIUMOK SPEKTRUMÁNAK IDŐBELI VÁLTOZÁSA A 2004-2017 KÖZÖTTI IDŐSZAKBAN 
ekkor az esetek 56\%-ában fordult elő, míg a legalacsonyabb érték 2016-ban volt mérhető: 39\%. Az Enterococcus faecalis gyakorisága szignifikánsan növekedett a vizsgálati időszakban: a 2004-ben észlelt 15\%-ról 2017-re 26\%-ra nőtt ( $p<0,0001)$. A Klebsiella pneumoniae átlagosan 11\% körüli előfordulása érdemben nem változott az évek során ( $p=0,797)$. A Pseudomonas aeruginosa aránya enyhén emelkedett $(p=0,044)$, míg a Proteus mirabilis aránya nem változott $(p=0,382)$, de mindkettő előfordulási aránya többnyire 10\% alatt maradt.

\section{Rezisztenciaviszonyok}

A baktériumok antibiotikum-rezisztencia arányainak összesítése az 1-6. táblázatokban látható.

\section{Fluorokinolonok (1. táblázat)}

Tizennégy év alatt az E. coli ciprofloxacin rezisztenciája szignifikánsan, 19\%-ról 25\%-ra nőtt $(p=0,039)$. A K. pneumoniae ciprofloxacin és norfloxacin rezisztenciája 26\% és 59\% között ingadozott. Az E. faecalis esetén a ciprofloxacin-rezisztencia végig magasabb volt, mint 47\%, míg a levofloxacin-rezisztencia 30-42\% közötti értékeket mutatott. A P. aeruginosa rezisztenciája ciprofloxacinnal és levofloxacinnal szemben csökkenő tendenciát mutatott, ami azonban nem volt szignifikáns: ciprofloxacin vonatkozásában 38\%-ról 15\%-ra ( $\mathrm{p}=0,086)$, míg levofloxacin esetében 38\%-ról 19\%-ra csökkent $(p=0,09)$. A P. mirabilis ciprofloxacin rezisztenciája $10 \%$ és 44\% között ingadozott a vizsgálati időszakban.

\section{Penicillinszármazékok (2. táblázat)}

Az E. coli esetében az ampicillinrezisztencia érdemben nem változott: 2004-ben 57\%-ot, 2017-ben 54\%-ot mutatott. Az E. faecalis ampicillin rezisztenciája sem nőtt, $0 \%$ és $2 \%$ között mozgott. A K. pneumoniae rezisztenciája szintén változatlan, $100 \%$ maradt. A P. mirabilis esetében ugyanakkor az ampicillinrezisztencia 2015-ig szignifikánsan emelkedett 20\%-ról

\section{TÁblÁZAT: REZISZTENCIA FLUOROKINOLONOKKAL SZEMBEN: A LEGGYAKORIBB KÓROKOZÓK CIPROFLOXACIN, LEVOFLOXA-} CIN ÉS NORFLOXACIN REZISZTENCIÁJA 2004 És 2017 KöZÖTT

\begin{tabular}{|c|c|c|c|c|c|c|c|c|c|c|c|c|c|c|c|c|}
\hline \multicolumn{11}{|c|}{ Ciprofloxacin-rezisztencia } & \multicolumn{6}{|c|}{ Levofloxacin-rezisztencia } \\
\hline \multirow[t]{2}{*}{ Év } & \multicolumn{2}{|r|}{ E. coli } & \multicolumn{2}{|c|}{ E. faecalis } & \multicolumn{2}{|c|}{$\begin{array}{l}\text { K. pneumo- } \\
\text { niae }\end{array}$} & \multicolumn{2}{|c|}{$\begin{array}{l}\text { P. aerugi- } \\
\text { nosa }\end{array}$} & \multicolumn{2}{|c|}{ P. mirabilis } & \multicolumn{2}{|c|}{ E. coli } & \multicolumn{2}{|c|}{ E. faecalis } & \multicolumn{2}{|c|}{$\begin{array}{l}\text { P. aerugi- } \\
\text { nosa }\end{array}$} \\
\hline & $\%$ & $(n / N)$ & $\%$ & $(n / N)$ & $\%$ & $(n / N)$ & $\%$ & $(n / N)$ & $\%$ & $(n / N)$ & $\%$ & $(n / N)$ & $\%$ & $(n / N)$ & $\%$ & $(n / N)$ \\
\hline 2004 & 19 & $(25 / 130)$ & 100 & $(38 / 38)$ & & V.M. & 38 & $(5 / 13)$ & & M. & 0 & $(0 / 22)$ & & N.M. & 38 & $(5 / 13)$ \\
\hline 2005 & 18 & $(25 / 140)$ & 100 & $(42 / 42)$ & & V.M. & 27 & $(3 / 11)$ & & M. & 0 & $(0 / 12)$ & & N.M. & 40 & $(4 / 10)$ \\
\hline 2006 & 22 & $(25 / 115)$ & 97 & $(34 / 35)$ & & V.M. & 36 & $(4 / 11)$ & & M. & 14 & $(1 / 7)$ & & N.M. & 40 & $(4 / 10)$ \\
\hline 2007 & 27 & $(22 / 83)$ & 100 & $(44 / 44)$ & & V.M. & 33 & $(4 / 12)$ & & M. & 12 & $(2 / 17)$ & & N.M. & 33 & $(4 / 12)$ \\
\hline 2008 & 15 & $(24 / 156)$ & 52 & $(34 / 66)$ & 34 & $(11 / 32)$ & 14 & $(1 / 7)$ & 50 & $(2 / 4)$ & 12 & $(2 / 17)$ & & N.M. & 17 & $(1 / 6)$ \\
\hline 2009 & 24 & $(28 / 116)$ & 96 & $(45 / 47)$ & 30 & $(6 / 20)$ & 22 & (2/9) & 38 & $(5 / 13)$ & 9 & $(1 / 11)$ & & N.M. & 25 & $(2 / 8)$ \\
\hline 2010 & 22 & $(24 / 107)$ & 47 & $(22 / 47)$ & 29 & $(6 / 21)$ & 19 & $(3 / 16)$ & 33 & $(4 / 12)$ & 0 & $(0 / 13)$ & & N.M. & 13 & $(2 / 15)$ \\
\hline 2011 & 32 & (34/108) & 56 & $(31 / 55)$ & 26 & $(7 / 27)$ & 15 & $(2 / 13)$ & 13 & $(1 / 8)$ & 0 & $(0 / 15)$ & & N.M. & 15 & $(2 / 13)$ \\
\hline 2012 & 24 & $(25 / 103)$ & 50 & $(9 / 18)$ & 59 & $(17 / 29)$ & 16 & $(3 / 19)$ & 44 & $(7 / 16)$ & 0 & $(0 / 25)$ & & N.M. & 38 & $(6 / 16)$ \\
\hline 2013 & 22 & $(23 / 103)$ & & N.M. & 32 & $(11 / 34)$ & 5 & $(1 / 20)$ & 13 & $(2 / 15)$ & & M. & & N.M. & 5 & $(1 / 20)$ \\
\hline 2014 & 25 & (33/131) & & N.M. & 29 & $(12 / 42)$ & 22 & $(10 / 45)$ & 19 & $(4 / 21)$ & & M. & 41 & $(24 / 59)$ & 22 & (10/45) \\
\hline 2015 & 25 & $(31 / 122)$ & & N.M. & 50 & $(11 / 22)$ & 13 & $(2 / 16)$ & 10 & $(2 / 20)$ & & M. & 40 & $(26 / 65)$ & 19 & $(3 / 16)$ \\
\hline 2016 & 24 & (31/131) & & N.M. & 49 & $(24 / 49)$ & 26 & $(10 / 38)$ & 24 & $(4 / 17)$ & & M. & 42 & $(42 / 100)$ & 28 & $(10 / 35)$ \\
\hline 2017 & 25 & (33/131) & & N.M. & 51 & $(19 / 37)$ & 15 & $(4 / 27)$ & 21 & $(4 / 19)$ & & M. & 30 & (22/73) & 19 & $(5 / 27)$ \\
\hline
\end{tabular}

\begin{tabular}{|cccccccc}
\hline \multicolumn{7}{c}{ Norfloxacin-rezisztencia } \\
\hline Év & E. coli & \multicolumn{3}{c}{ K. pneumo- } \\
niae & \multicolumn{2}{c}{ P. mirabilis } \\
& $\%$ & $(\mathrm{n} / \mathrm{N})$ & $\%$ & $(\mathrm{n} / \mathrm{N})$ & $\%$ & $(\mathrm{n} / \mathrm{N})$ \\
\hline 2008 & 14 & $(22 / 153)$ & 36 & $(12 / 33)$ & 50 & $(2 / 4)$ \\
\hline 2009 & 18 & $(21 / 116)$ & 35 & $(7 / 20)$ & 46 & $(6 / 13)$ \\
\hline 2010 & 22 & $(24 / 107)$ & 29 & $(6 / 21)$ & 33 & $(4 / 12)$ \\
\hline 2011 & 32 & $(34 / 106)$ & 26 & $(7 / 27)$ & 13 & $(1 / 8)$ \\
\hline 2012 & 25 & $(25 / 102)$ & 57 & $(17 / 30)$ & 44 & $(7 / 16)$ \\
\hline 2013 & 23 & $(23 / 102)$ & 32 & $(11 / 34)$ & 13 & $(2 / 15)$ \\
\hline 2014 & 25 & $(32 / 128)$ & 29 & $(12 / 42)$ & 20 & $(4 / 20)$ \\
\hline 2015 & 25 & $(31 / 122)$ & 48 & $(10 / 21)$ & 10 & $(2 / 20)$ \\
2016 & 24 & $(31 / 131)$ & 50 & $(24 / 48)$ & 24 & $(4 / 17)$ \\
2017 & 25 & $(33 / 132)$ & 51 & $(19 / 37)$ & 21 & $(4 / 19)$
\end{tabular}

N.M. = nincs meghatározva 40\%-ra ( $\mathrm{p}=0,007)$, majd az ezt követő években csökkenő tendenciát mutatott. Az E. coli amoxicillin/klavulánsav rezisztenciája 6\% és 35\% között ingadozott. A K. pneumoniae esetén pedig szignifikánsan nőtt 17\%-ról 62\%-ra ( $p<0,0001)$. Amoxicillin/klavulánsav szemben a P. mirabilis rezisztenciája az évek döntő többségében $10 \%$ alatti értékeket mutatott.

\section{Karbapenemek (3. táblázat)}

Imipenem, meropenem és ertapenem vonatkozásában nem észleltünk számottevő mennyiségú rezisztens $E$. coli, K. pneumoniae, $E$. faecalis és $P$. mirabilis törzset a vizsgálati időszakban. A $P$. aeruginosa ugyanakkor jelentős rezisztencianövekedést mutatott imipenemmel szemben, míg 2010-ben $6 \%$, 2017-ben már 19\%-os értéket mértünk ( $p=0,004)$. 


\section{Cefalosporinok (4. táblázat)}

E. coli esetében a cefuroximrezisztencia enyhén, nem szignifikáns mértékben emelkedett 8\%-ról 14\%-ra $(p=0,741)$. A K. pneumoniae cefuroxim rezisztenciája $24 \%$ és $60 \%$ között váltakozott, míg P. mirabilis esetén 8\%-nál magasabb érték nem volt tapasztalható. A cefixim vonatkozásában az E. coli rezisztenciája nem haladta meg a 14\%-ot, míg P. mirabilis esetében csak 2017-ben találkoztunk rezisztens törzsekkel, az esetek 16\%-ában. K. pneumoniae esetén statisztikailag nem szignifikáns rezisztencianövekedés volt tapasztalható cefiximmel szemben: 2010-ben 29\%-os, míg 2017-ben 51\%-os arányt mértünk $(p=0,075)$. Ceftriaxonnal szemben az $E$. coli rezisztenciája szignifikáns emelkedést mutatott. Míg 2004-ben 1\% volt, 2017-ig ez az arány 12\%-ig emelkedett $(p<0,0001)$. $K$. pneumoniae esetében a ceftriaxon-rezisztencia $24 \%$ (és $57 \%$ között ingadozott a vizsgálati időszak második felében, míg $P$. mirabilis esetében ceftriaxon-rezisztenciát nem észleltünk. A $P$. aeruginosa ceftazidim rezisztenciája 0\% (0/20) és 16\% (3/19) között ingadozott. Az E. coli cefepim rezisztenciája szignifikáns növekedést mutatott $(p<0,0001)$. Míg 2004-ben 1\%-0s, 2012ben már 8\%-os értékeket számoltunk. Cefepimmel szemben a K. pneumoniae rezisztenciája 2012-ben elérte a 40\%-ot. A $P$. aeruginosa és $P$. mirabilis esetén észlelt rezisztenciaarányok cefepimmel szemben csökkenő tendenciát mutattak. Míg $P$. aeruginosa esetében $15 \%$-ról $4 \%$-ra $(\mathrm{p}=0,45)$, $P$. mirabilis vonatkozásában 10\%-ról 0\%-ra csökkent ( $\mathrm{p}=0,331$ ), bár ezek az változások nem voltak statisztikailag szignifikánsak.

\section{Aminoglikozidok (5. táblázat)}

A gentamicin-rezisztencia E. coli törzsek esetén 7\% alatt maradt, miközben $E$. faecalis vonatkozásában szignifikánsan csökkent 100\%-ról 48\%-ra ( $\mathrm{p}<0,0001)$. P. aeruginosa esetén 31\%-ról 7\%-ra, míg P. mirabilis esetén 30\%-ról 12\%-ra csökkent $(p=0,013$ és $p=0,002)$. Csupán a $K$. pneumoniae gentamicin rezisztenciája mutatott szignifikáns, 0\%-ról 32\%-ra történő emelkedést $(p<0,0001)$.

AzE. coli amikacin rezisztenciája szignifikánsan csökkent $(p=0,003)$ : míg 2004-ben az arány 4\% volt, 2011-ben 0\%-os értéket számoltunk. Az ezt követő években mértékét rutinszerúen már nem vizsgáltuk. A P. aeruginosa rezisztenciája amikacinnal szemben az utóbbi években nem haladta meg a $6 \%$-ot. $K$. pneumoniae és P. mirabilis esetén sem észleltünk jelentős amikacin-rezisztenciát.

\section{Trimetoprim/szulfametoxazol (6. a táblázat)}

Az E. coli esetén számított trimetoprim/szulfametoxazol rezisztencia 19\% (2015-ben) és 32\% között ingadozott. K. pneumoniae vonatkozásában aránya szignifikánsan, a 2004ben észlelt 13\%-ról 2017-ben mért 44\%-ra nőtt ( $p<0,0001)$. Legmagasabb értékét 2012-ben érte el, ekkor 63\%-os rezisztenciaarányt mutatott. P. mirabilis esetén a rezisztencia $20 \%$ és $63 \%$ között mozgott.

\section{Nitrofurantoin (6. a táblázat)}

Az E. coli nitrofurantoin rezisztenciája összességben nem haladta meg a 2\%-ot, ezzel szemben a K. pneumoniae és P. mirabilis esetében elérte a 100\%-ot.

\section{Foszfomicin (6. b táblázat)}

A foszfomicinnel szemben kialakuló rezisztenciát 2010 és 2012 között vizsgáltuk. E. coli esetében 0-5\%, K. pneumoniae vonatkozásában 0-15\%, P. mirabilis esetén pedig 0-14\%-os értékeket kaptunk.

2. tÁblÁzAT: ReZISZTENCIA PENICILLIN-SZÁrMAZÉKOKKAL SZEMBEN: A LEGGYAKORIBB KÓROKOZÓK AMPICILLIN ÉS AMOXICILLIN/KLAVULÁNSAV REZISZTENCIÁJA 2004 És 2017 KöZÖTt

\begin{tabular}{|c|c|c|c|c|c|c|c|c|c|c|c|c|c|c|}
\hline \multicolumn{9}{|c|}{ Ampicillin-rezisztencia } & \multicolumn{6}{|c|}{ Amoxicillin/klavulánsav-rezisztencia } \\
\hline \multirow[t]{2}{*}{ Év } & \multicolumn{2}{|c|}{ E. coli } & \multicolumn{2}{|c|}{ E. faecalis } & \multicolumn{2}{|c|}{$\begin{array}{l}\text { K. pneumo- } \\
\text { niae }\end{array}$} & \multicolumn{2}{|c|}{ P. mirabilis } & \multicolumn{2}{|c|}{ E. coli } & \multicolumn{2}{|c|}{$\begin{array}{l}\text { K. pneumo- } \\
\text { niae }\end{array}$} & \multicolumn{2}{|c|}{ P. mirabilis } \\
\hline & $\%$ & $(n / N)$ & $\%$ & $(n / N)$ & $\%$ & $(n / N)$ & $\%$ & $(n / N)$ & $\%$ & $(n / N)$ & $\%$ & $(n / N)$ & $\%$ & $(n / N)$ \\
\hline 2004 & 57 & $(74 / 130)$ & 0 & $(0 / 38)$ & 100 & $(23 / 23)$ & 20 & $(2 / 10)$ & 23 & $(30 / 130)$ & 17 & $(4 / 23)$ & 10 & $(1 / 10)$ \\
\hline 2005 & 40 & $(56 / 140)$ & 0 & $(0 / 42)$ & 88 & $(23 / 26)$ & 25 & (2/8) & 14 & $(20 / 140)$ & 19 & $(5 / 26)$ & 0 & $(0 / 8)$ \\
\hline 2006 & 53 & $(61 / 115)$ & 0 & $(0 / 35)$ & 100 & $(13 / 13)$ & 18 & $(2 / 11)$ & 28 & $(32 / 115)$ & 23 & $(3 / 13)$ & 9 & $(1 / 11)$ \\
\hline 2007 & 48 & $(40 / 83)$ & 2 & $(1 / 44)$ & 100 & $(28 / 28)$ & 21 & $(3 / 14)$ & 18 & $(15 / 83)$ & 14 & $(4 / 28)$ & 7 & $(1 / 14)$ \\
\hline 2008 & 49 & $(76 / 156)$ & 0 & $(0 / 66)$ & 100 & (33/33) & 50 & $(2 / 4)$ & 6 & $(10 / 156)$ & 6 & $(2 / 33)$ & 25 & $(1 / 4)$ \\
\hline 2009 & 52 & $(60 / 116)$ & 0 & $(0 / 47)$ & 100 & $(20 / 20)$ & 23 & (3/13) & 19 & $(22 / 116)$ & 15 & $(3 / 20)$ & 8 & $(1 / 13)$ \\
\hline 2010 & 67 & $(72 / 107)$ & 0 & $(0 / 47)$ & 100 & $(21 / 21)$ & 33 & $(4 / 12)$ & 17 & $(18 / 107)$ & 33 & (7/21) & 0 & $(0 / 12)$ \\
\hline 2011 & 57 & $(61 / 107)$ & 2 & $(1 / 55)$ & 100 & $(27 / 27)$ & 38 & (3/8) & 23 & $(25 / 107)$ & 26 & $(7 / 27)$ & 13 & $(1 / 8)$ \\
\hline 2012 & 52 & $(53 / 103)$ & 0 & $(0 / 71)$ & 100 & $(29 / 29)$ & 44 & $(7 / 16)$ & 15 & $(15 / 103)$ & 57 & (17/30) & 0 & (0/16) \\
\hline 2013 & 45 & $(46 / 103)$ & 1 & $(1 / 82)$ & 100 & $(34 / 34)$ & 53 & $(8 / 15)$ & 14 & $(14 / 103)$ & 47 & $(16 / 34)$ & 7 & $(1 / 15)$ \\
\hline 2014 & 60 & $(78 / 131)$ & 0 & $(0 / 90)$ & 100 & $(42 / 42)$ & 52 & $(11 / 21)$ & 35 & $(46 / 131)$ & 38 & $(16 / 42)$ & 19 & $(4 / 21)$ \\
\hline 2015 & 54 & $(66 / 122)$ & 0 & $(0 / 70)$ & 100 & $(22 / 22)$ & 40 & $(8 / 20)$ & 28 & $(34 / 122)$ & 59 & $(13 / 22)$ & 5 & $(1 / 20)$ \\
\hline 2016 & 54 & $(71 / 132)$ & 2 & $(2 / 105)$ & 100 & (49/49) & 35 & $(6 / 17)$ & 18 & (24/132) & 53 & (26/49) & 6 & $(1 / 17)$ \\
\hline 2017 & 54 & (72/133) & 0 & $(0 / 79)$ & 100 & (37/37) & 32 & $(6 / 19)$ & 26 & $(35 / 133)$ & 62 & $(23 / 37)$ & 11 & $(2 / 19)$ \\
\hline
\end{tabular}




\section{Polimixin B (6. b táblázat)}

$E$. coli, K. pneumoniae és $P$. mirabilis esetében a vizsgálati idószakban egyáltalán nem észleltünk rezisztenciát Polimixin B-vel szemben, viszont a P. mirabilis gyakorlatilag $100 \%$-os rezisztenciát mutatott.

Az E. faecalis rezisztenciája vancomycinnel szemben a vizsgálati időszakban végig $0 \%$ volt.

A P. aeruginosa kolisztin rezisztenciája $0 \%$ és $8 \%$ között, tobramycin rezisztenciája pedig $0 \%$ és $16 \%$ között változott, míg piperacillin/tazobactam rezisztenciája 2017-ben elérte a 12\%-ot.

\section{Megbeszélés}

A hospitalizált betegek húgyúti fertőzéseinek megfelelő kezeléséhez a helyileg előforduló húgyúti kórokozók spektrumának és antibiotikum-rezisztenciáának ismerete szükséges, ezért rendkivül fontos ezen adatok évről évre történő felmérése. Ezen adatok ismerete segítségül szolgálhat a megfelelő antibiotikum kiválasztásakor húgyúti fertőzések empirikus kezelése, illetve sebészeti mútéti profilaxis során $(9,10)$.

A legnagyobb urológiai nozokomiális infekciókat és bakteriális antibiotikum rezisztenciaviszonyokat felmérő nemzetközi prevalencia vizsgálat a Global Prevalence of Infections in Urology (GPIU) study. Ennek során minden évben világszerte felmérik a rezisztenciaviszonyokat, a nozokomiális húgyúti fertőzések előfordulását, rizikófaktorait és az antibiotikum-kezelési szokásokat. A GPIU legutóbbi 2003-2010-es adatainak összegzése szerint Észak-Európában, ahova Magyarországot is besorolták, a leggyakoribb kórokozó az Escherichia coli (36\%) és az Enterococcus species (14\%) (11). A Jahn Ferenc Dél-pesti Kórház és Rendelőintézet Urológiai Osztályán az esetek körülbelül felében $E$. coli tenyészett ki, amely arány magasabb, mint az észak-európai országokban és inkább megközelíti a dél-európai országokban észlelt 55\%-os értéket. Az E. coli aránya az évek során csökkenő tendenciát mutat. A második leggyakoribb kórokozó osztályunkon az Enterococcus faecalis (2017ben $26 \%$ ). Arányának növekedése az endourológiai beavatkozások és húgyúti idegentestek elterjedésével magyarázható, amit figyelembe kell vennünk az antibiotikum-kiválasztáskor empirikus kezelések során.

A bakteriális antibiotikum-rezisztencia tekintetében ellentmondó eredmények születtek. A 2003-2010-es GPIU-vizsgálat során nem észleltek egyértelmú bakteriális rezisztencianövekedést a legtöbb antibiotikummal szemben, míg osztályunkon néhány antibiotikum vonatkozásában szignifikáns rezisztenciaemelkedést tapasztaltunk. Az E. coli ciprofloxacin-rezisztenciája szignifikánsan nőtt 19\%-ról 25\%-ra. Bár ezen érzékek alacsonyabbak, mint a GPIU-vizsgálatban észlelt arányok, mégis túl magasak ahhoz, hogy biztonsággal alkalmazzuk őket empirikus kezelés során. A K. pneumoniae ciprofloxacin-rezisztenciája szintén magasnak bizonyult, 26\%-59\% között

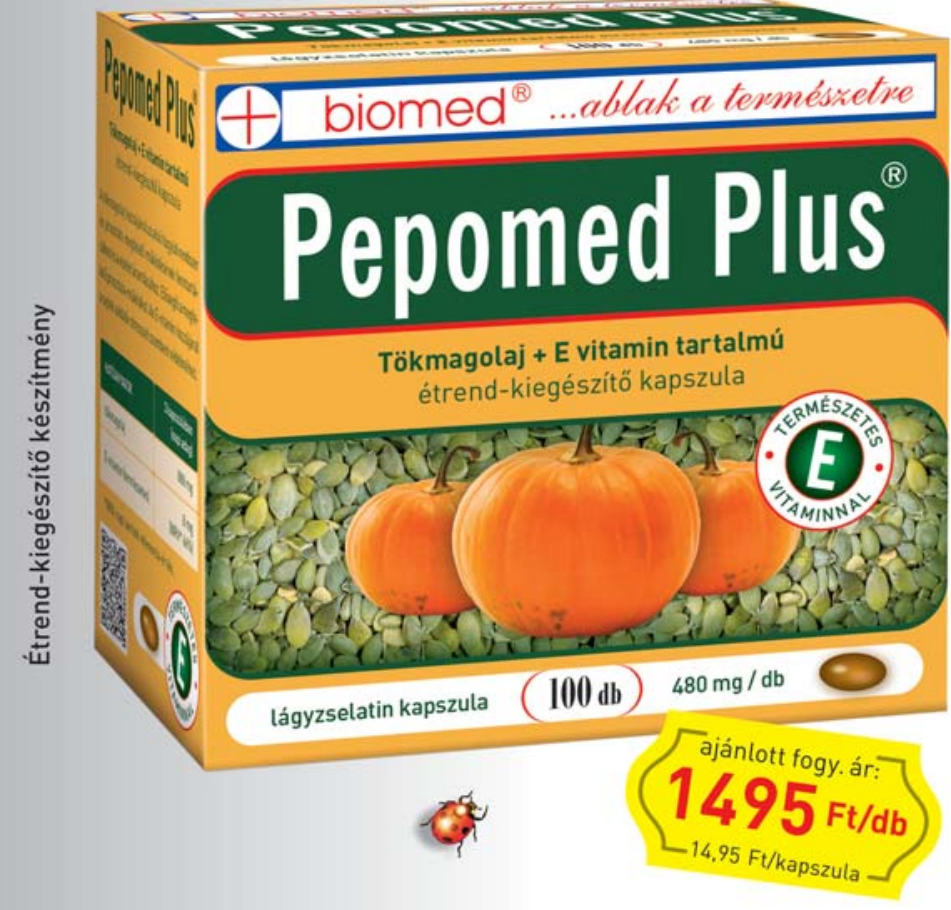

\section{Az alsó húgyúti rendszer és prosztata megfelelő müködésének fenntartásához.}

\author{
- Tökmagolaj + E-vitamin tartalmú étrend- \\ kiegészítő kapszula. \\ - Könnyen nyelhető és nincs utóize. \\ - Biztonságos és higiénikus blisztercsomagolás. \\ - $100 \mathrm{db}, 480 \mathrm{mg} / \mathrm{db}$.
}


3. tÁblÁzAt: REZisZtencia KARBAPENEMEKKEl SZEMBEN: A LEGGYAKORIBB KÓROKOZÓK IMIPENEM, MEROPENEM ÉS ERTAPENEM REZISZTENCIÁJA 2008 ÉS 2017 KÖZÖTT

\begin{tabular}{|c|c|c|c|c|c|c|c|c|c|c|c|c|c|c|}
\hline \multicolumn{15}{|c|}{ Imipenem-rezisztencia } \\
\hline \multirow[t]{2}{*}{ Év } & \multicolumn{2}{|c|}{ E. coli } & \multicolumn{2}{|c|}{ E. faecalis } & \multicolumn{2}{|c|}{$\begin{array}{l}\text { K. pneumo- } \\
\text { niae }\end{array}$} & \multicolumn{2}{|c|}{ P. aeruginosa } & \multicolumn{2}{|c|}{ P. mirabilis } & & & & \\
\hline & $\%$ & $(n / N)$ & $\%$ & $(n / N)$ & $\%$ & $(n / N)$ & $\%$ & $(n / N)$ & $\%$ & $(n / N)$ & & & & \\
\hline 2008 & 0 & $(0 / 156)$ & \multicolumn{2}{|c|}{ N.M. } & 0 & $(0 / 33)$ & 0 & $(0 / 7)$ & 25 & $(1 / 4)$ & & & & \\
\hline 2009 & 0 & $(0 / 116)$ & \multicolumn{2}{|c|}{ N.M. } & 0 & $(0 / 20)$ & 0 & $(0 / 9)$ & 15 & $(2 / 13)$ & & & & \\
\hline 2010 & 0 & $(0 / 107)$ & \multicolumn{2}{|c|}{ N.M. } & 0 & $(0 / 21)$ & 6 & $(1 / 16)$ & 0 & $(0 / 12)$ & & & & \\
\hline 2011 & 0 & (0/108) & \multicolumn{2}{|c|}{ N.M. } & 0 & $(0 / 27)$ & 15 & $(2 / 13)$ & 0 & $(0 / 8)$ & & & & \\
\hline 2012 & 0 & $(0 / 101)$ & 0 & $(0 / 14)$ & 0 & $(0 / 30)$ & 5 & $(1 / 19)$ & 0 & $(0 / 16)$ & & & & \\
\hline 2013 & 0 & (0/103) & 0 & $(0 / 9)$ & 0 & $(0 / 32)$ & 5 & $(1 / 20)$ & 0 & $(0 / 15)$ & & & & \\
\hline 2014 & 0 & (0/131) & 0 & $(0 / 10)$ & 0 & $(0 / 42)$ & 16 & $(7 / 45)$ & 0 & $(0 / 21)$ & & & & \\
\hline 2015 & 0 & $(0 / 122)$ & 0 & $(0 / 49)$ & 0 & $(0 / 22)$ & 27 & $(4 / 15)$ & 0 & $(0 / 19)$ & & & & \\
\hline 2016 & 0 & $(0 / 132)$ & 1 & $(1 / 105)$ & 0 & $(0 / 49)$ & 26 & $(10 / 38)$ & 0 & $(0 / 2)$ & & & & \\
\hline 2017 & 0 & $(0 / 132)$ & 0 & $(0 / 78)$ & 0 & $(0 / 36)$ & 19 & $(5 / 27)$ & & N.M. & & & & \\
\hline \multicolumn{9}{|c|}{ Meropenem-rezisztencia } & \multicolumn{6}{|c|}{ Ertapenem-rezisztencia } \\
\hline \multirow[t]{2}{*}{ Év } & \multicolumn{4}{|c|}{$\begin{array}{l}\text { K. pneumo- } \\
\text { niae }\end{array}$} & \multicolumn{2}{|c|}{ P. aeruginosa } & \multicolumn{2}{|c|}{ P. mirabilis } & \multicolumn{2}{|c|}{ E. coli } & \multicolumn{2}{|c|}{$\begin{array}{l}\text { K. pneumo- } \\
\text { niae }\end{array}$} & \multicolumn{2}{|c|}{ P. mirabilis } \\
\hline & $\%$ & $(n / N)$ & $\%$ & $(n / N)$ & $\%$ & $(n / N)$ & $\%$ & $(n / N)$ & $\%$ & $(n / N)$ & $\%$ & $(n / N)$ & $\%$ & $(\mathrm{n} / \mathrm{N})$ \\
\hline 2010 & 0 & $(0 / 85)$ & 0 & $(0 / 16)$ & 0 & $(0 / 16)$ & 0 & $(0 / 12)$ & 0 & $(0 / 107)$ & 0 & $(0 / 21)$ & 0 & $(0 / 12)$ \\
\hline 2011 & 0 & $(0 / 108)$ & 0 & $(0 / 22)$ & 15 & $(2 / 13)$ & 0 & $(0 / 8)$ & 0 & $(0 / 108)$ & 0 & $(0 / 27)$ & 0 & $(0 / 8)$ \\
\hline 2012 & 0 & $(0 / 75)$ & 0 & $(0 / 20)$ & 5 & $(1 / 19)$ & 0 & $(0 / 11)$ & 0 & $(0 / 103)$ & 0 & $(0 / 30)$ & 0 & $(0 / 16)$ \\
\hline 2013 & 0 & $(0 / 99)$ & 0 & $(0 / 31)$ & 0 & $(0 / 20)$ & 0 & $(0 / 15)$ & 0 & $(0 / 103)$ & 0 & $(0 / 34)$ & 0 & $(0 / 15)$ \\
\hline 2014 & 0 & (0/131) & 0 & $(0 / 41)$ & 16 & (7/45) & 0 & $(0 / 21)$ & 0 & (0/131) & 0 & $(0 / 42)$ & 0 & $(0 / 21)$ \\
\hline 2015 & 0 & $(0 / 121)$ & 0 & $(0 / 22)$ & 19 & $(3 / 16)$ & 0 & $(0 / 19)$ & 0 & $(0 / 122)$ & 0 & $(0 / 22)$ & 0 & $(0 / 20)$ \\
\hline 2016 & 0 & (0/129) & 0 & $(0 / 49)$ & 18 & $(7 / 38)$ & 0 & $(0 / 17)$ & 0 & (0/132) & 0 & $(0 / 49)$ & 0 & $(0 / 17)$ \\
\hline 2017 & 0 & $(0 / 132)$ & 0 & $(0 / 36)$ & 15 & $(4 / 27)$ & 0 & $(0 / 19)$ & 0 & (0/133) & 0 & $(0 / 37)$ & 0 & $(0 / 19)$ \\
\hline
\end{tabular}

N.M. - nincs meghatározva

ingadozott, ami megfelel a nemzetközi adatoknak. Az E. faecalis ciprofloxacin és levofloxacin rezisztenciája meghaladta az 47\%, illetve 30\%-ot. A P. aeruginosa ciprofloxacin-rezisztenciája csökkenő tendenciát mutat, 2017-ben 15\%-os értéket ért el, viszont ez az eredmény nem tekinthető statisztikailag szignifikánsnak. Ezen adatok alapján a fluorokinolonok nem javasolhatók többé húgyúti fertőzések empirikus kezelésére régiónkban. A cefalosporinokkal szemben az E. coli rezisztenciája 20\% alatt maradt. Ennek lehetséges oka a megváltozott antibiotikum-felhasználási stratégiánk, miszerint visszaszorítottuk a fluorokinolonok alkalmazását és csökkentettük a cefalosporinokét. Ennek ellenére, E. coli esetében szignifikáns rezisztencianövekedést tapasztaltunk ceftriaxonnal szemben, amely elérte a 12\%-ot ( $p<0,0001)$, ezáltal 2017-re meghaladta az empirikus kezeléshez ajánlott $10 \%$-os küszöböt. A K. pneumoniae cefalosporin-rezisztenciája igen magasnak bizonyult, ami megfelel a nemzetközi megfigyeléseknek. Negyedik generációs cefalosporinnal, a cefepimmel szemben a K. pneumoniae rezisztenciája 2012-ben elérte a 40\%-ot. A K. pneumoniae magas rezisztenciájának hátterében felté- telezhetően a multirezisztens, ESBL-pozitív K. pneumoniae arányának növekedése állhat (11). Eredményeink alapján a cefalosporinok jó empirikusan választható antibiotikumoknak tekinthetők Gram-negatív húgyúti fertőzések kezelése során, de kerülendők abban az esetben, ha multirezisztens kórokozó gyanúja felmerül. Mivel az Enterococcus faecalis természetes rezisztenciával bír cefalosporinokkal szemben, húgyúti idegen testek jelenlétében a várható magasabb arányát figyelembe kell vennünk az empirikus antibiotikum-választás során. Meglepő tény, hogy nem észleltünk ceftriaxon- és ceftazidim-rezisztenciát a vizsgálati időszakban Proteus mirabilis esetében, ami a viszonylag alacsony Proteus mirabilis izolátumszámmal magyarázható (átlagosan 13-15 minta évente). A legtöbb kórokozó minimális rezisztenciát mutatott karbapenemekkel szemben, ugyanakkor a $P$. aeruginosa szignifikáns $(p=0,004)$ rezisztencianövekedése aggodalomra adhat okot. A 2010ben észlelt 6\%-os imipenem rezisztenciája 2017-ben 19\%-ra emelkedett. Az urológiai osztályokon világszerte növekvő karbapenem-rezisztenciáról a GPIU-vizsgálat és más nemzetközi vizsgálatok is beszámoltak (12). 
4. tÁblÁZAT: REZISZTENCIA CEFALOSPORINOKKAL SZEMBEN: A LEGGYAKORIBB KÓROKOZÓK CEFAMANDOL, CEFUROXIM, CEFTRIAXON, CEFIXIM, CEFTAZIDIM ÉS CEFEPIM REZISZTENCIÁJA 2004 ÉS 2017 KÖZÖTT

\begin{tabular}{|ccccccc}
\hline \multicolumn{5}{c}{ Cefamandol-rezisztencia } \\
\hline Év & \multicolumn{3}{c}{ E. coli } & \multicolumn{3}{c|}{ K. pneu- } \\
moniae & $\begin{array}{c}\text { P. mira- } \\
\text { bilis }\end{array}$ \\
& $\%$ & $(\mathrm{n} / \mathrm{N})$ & $\%$ & $(\mathrm{n} / \mathrm{N})$ & $\%$ & $(\mathrm{n} / \mathrm{N})$ \\
\hline 2004 & 4 & $(5 / 130)$ & 4 & $(1 / 23)$ & 0 & $(0 / 10)$ \\
\hline 2005 & 5 & $(7 / 140)$ & 8 & $(2 / 26)$ & 13 & $(1 / 8)$ \\
\hline 2006 & 16 & $(18 / 115)$ & 0 & $(0 / 13)$ & 18 & $(2 / 11)$ \\
2007 & 4 & $(3 / 83)$ & 4 & $(1 / 28)$ & 21 & $(3 / 14)$ \\
2008 & 0 & $(0 / 156)$ & 3 & $(1 / 33)$ & 0 & $(0 / 4)$ \\
2009 & 7 & $(8 / 116)$ & 5 & $(1 / 20)$ & 8 & $(1 / 13)$ \\
2010 & 7 & $(7 / 107)$ & 0 & $(0 / 21)$ & 0 & $(0 / 12)$ \\
\hline
\end{tabular}



N.M. - nincs meghatározva 
5. tÁbLÁZAT: REZISZTENCIA AMINOGLOKOZIDOKKAL SZEMBEN: LEGGYAKORIBB KÓROKOZÓK GENTAMICIN ÉS AMIKACIN REZISZTENCIÁJA 2004 És 2017 KÖZÖTT

\begin{tabular}{|c|c|c|c|c|c|c|c|c|c|c|c|c|c|c|c|c|c|c|}
\hline \multicolumn{11}{|c|}{ Gentamicin-rezisztencia } & \multicolumn{8}{|c|}{ Amikacin-rezisztencia } \\
\hline \multirow[t]{2}{*}{ Év } & \multicolumn{2}{|c|}{ E. coli } & \multicolumn{2}{|c|}{ E. faecalis } & \multicolumn{2}{|c|}{$\begin{array}{l}\text { K. pneu- } \\
\text { moniae }\end{array}$} & \multicolumn{2}{|c|}{$\begin{array}{l}\text { P. aerugi- } \\
\text { nosa }\end{array}$} & \multicolumn{2}{|c|}{ P. mirabilis } & \multicolumn{2}{|c|}{ E. coli } & \multicolumn{2}{|c|}{$\begin{array}{l}\text { K. pneu- } \\
\text { moniae }\end{array}$} & \multicolumn{2}{|c|}{$\begin{array}{l}\text { P. aerugi- } \\
\text { nosa }\end{array}$} & \multicolumn{2}{|c|}{$\begin{array}{l}\text { P. mira- } \\
\text { bilis }\end{array}$} \\
\hline & $\%$ & $(\mathrm{n} / \mathrm{N})$ & $\%$ & $(n / N)$ & $\%$ & $(n / N)$ & $\%$ & $(n / N)$ & $\%$ & $(n / N)$ & $\%$ & $(n / N)$ & $\%$ & $(n / N)$ & $\%$ & $(n / N)$ & & $(n / N)$ \\
\hline 2004 & 6 & $(8 / 130)$ & 100 & $(38 / 38)$ & 0 & $(0 / 23)$ & 31 & $(4 / 13)$ & 30 & $(3 / 10)$ & 4 & $(5 / 130)$ & & M. & 0 & $(0 / 13)$ & & I.M. \\
\hline 2005 & 7 & $(10 / 140)$ & 100 & $(42 / 42)$ & 4 & $(1 / 26)$ & 36 & $(4 / 11)$ & 38 & $(3 / 8)$ & 3 & $(4 / 140)$ & & M. & 0 & $(0 / 11)$ & & I.M. \\
\hline 2006 & 4 & $(5 / 115)$ & 100 & $(35 / 35)$ & 0 & $(0 / 13)$ & 45 & $(5 / 11)$ & 45 & $(5 / 11)$ & 1 & $(1 / 115)$ & & M. & 18 & $(2 / 11)$ & & J.M. \\
\hline 2007 & 5 & $(4 / 83)$ & 100 & $(44 / 44)$ & 4 & $(1 / 28)$ & 33 & $(4 / 12)$ & 29 & $(4 / 14)$ & 7 & $(6 / 83)$ & & M. & 0 & $(0 / 12)$ & & M. \\
\hline 2008 & 0 & $(0 / 156)$ & 53 & $(35 / 66)$ & 0 & $(0 / 33)$ & 0 & $(0 / 7)$ & 25 & $(1 / 4)$ & 0 & $(0 / 7)$ & 0 & $(0 / 2$ & 0 & $(0 / 7)$ & 0 & $(0 / 1)$ \\
\hline 2009 & 4 & $(5 / 116)$ & 100 & (47/47) & 0 & $(0 / 20)$ & 22 & $(2 / 9)$ & 15 & $(2 / 13)$ & 0 & (0/116) & 0 & $(0 / 20)$ & 0 & $(0 / 9)$ & 0 & $(0 / 13)$ \\
\hline 2010 & 4 & $(4 / 107)$ & 38 & $(18 / 47)$ & 24 & $(5 / 21)$ & 0 & $(0 / 16)$ & 8 & $(1 / 12)$ & 0 & (0/107) & 0 & $(0 / 21)$ & 0 & (0/16) & 0 & $(0 / 12)$ \\
\hline 2011 & 3 & $(3 / 108)$ & 38 & $(21 / 55)$ & 30 & $(8 / 27)$ & 15 & $(2 / 13)$ & 0 & $(0 / 8)$ & 0 & (0/108) & 0 & $(0 / 27)$ & 0 & (0/13) & 0 & $(0 / 8)$ \\
\hline 2012 & 1 & $(1 / 72)$ & 53 & (38/71) & 36 & (10/28) & 21 & $(4 / 19)$ & 6 & $(1 / 16)$ & 0 & $(0 / 21)$ & 10 & $(1 / 10)$ & 0 & (0/19) & 0 & $(0 / 5)$ \\
\hline 2013 & 2 & $(2 / 103)$ & 44 & (36/82) & 21 & $(7 / 34)$ & 5 & $(1 / 20)$ & 20 & $(3 / 15)$ & 0 & (0/1) & 0 & $(0 / 3)$ & 5 & $(1 / 20)$ & 0 & (0/4) \\
\hline 2014 & 5 & $(6 / 131)$ & 50 & $(45 / 90)$ & 2 & $(1 / 42)$ & 18 & (8/45) & 14 & $(3 / 21)$ & 0 & (0/3) & 0 & $(0 / 1)$ & 2 & $(1 / 45)$ & 0 & $(0 / 1)$ \\
\hline 2015 & 6 & $(7 / 122)$ & 50 & $(35 / 70)$ & 36 & (8/22) & 13 & $(2 / 16)$ & 15 & $(3 / 20)$ & 0 & $(0 / 1)$ & 0 & $(0 / 1)$ & 6 & (1/16) & 0 & $(0 / 2)$ \\
\hline 2016 & 6 & $(8 / 132)$ & 49 & $(5 V / 105)$ & 25 & (12/49) & 21 & (8/38) & 0 & $(0 / 17)$ & 0 & (0/1) & 0 & $(0 / 1)$ & 3 & $(1 / 37)$ & & N.M. \\
\hline 2017 & 2 & $(2 / 133)$ & 48 & (38/79) & 32 & $(12 / 37)$ & 7 & $(2 / 27)$ & 12 & $(2 / 17)$ & & N.M. & & N.M. & 0 & (0/25) & & N.M. \\
\hline
\end{tabular}

N.M. - nincs meghatározva

A kórokozók többségének trimetoprim/szulfametoxazol, foszfomicin és nitrofurantoin antibiotikumokkal szemben mért rezisztenciája elfogadható mértékú volt az utóbbi években, annak ellenére, hogy ezen antibiotikumokat, gyakrabban alkalmaztuk enyhébb nem komplikált húgyúti fertőzések esetén fluorokinolonok és cefalosporinok helyett. Ezáltal ezek az antibiotikumok továbbra is hatékonyan helyettesíthetik a fluorokinolonokat, különösen nem komplikált alsó húgyúti fertőzések empirikus kezelése során. Gentamicint osztályunkon, toxicitása miatt, igen ritkán alkalmazunk. Ennek megfelelően a baktériumok gentamicin-rezisztenciája elfogadhatóan alacsony szinten maradt, kivéve K. pneumoniae esetén, ahol szignifikánsan emelkedő értékeket mértünk.

A GPIU eredményei alapján a hospitalizált betegek 9\%-ánál alakul ki nozokomiális fertőzés. llyenkor gyakran multirezisztens kórokozó áll a fertőzés hátterében, amit az empirikus kezelés során, az antibiotikum megválasztásakor figyelembe kell vennünk. Ezért, amennyiben multirezisztens kórokozóra gyanakszunk, törekednünk kell arra, hogy a várható kórokozó érzékenységének megfelelő antibiotikumot válasszuk (pl.: karbapenemek, vagy anti-Pseudomonas aktivitással bíró béta-laktámok). Azt is figyelembe kell vennünk, hogy a legtöbb széles spektrumú antibiotikum, mint a fluorokinolonok és a cefalosporinok összefüggésbe hozhatók a Clostridium difficile fertőzések növekvő előfordulásával (13).

A 2010-es évet követő időszakra vonatkozó nemzetközi GPIU-vizsgálatok adatainak feldolgozása jelenleg is zajlik, amelyeknek a saját adatainkkal történő összehasonlítása a későb- biekben hasznos információval szolgálhat az antibiotikum-kezelési stratégiánk hatékonyságát illetően.

\section{Vizsgálatunk korlátai}

2010-ig, korlátozott adatmennyiséghez fértünk hozzá a mikrobiológiai laborból a számítógépes rendszer és az elektronikus adatbázis hiánya miatt. A 2010-es évtől kezdve az informatikai rendszer kiépítése jelentősen kiterjesztette az adatok feldolgozásának lehetőségeit. A mikrobiológiai adatgyúijésből kifolyólag nem állnak rendelkezésre klinikai háttéradatok a tenyésztésekkel kapcsolatban (tünetmentes bakteriuria vagy tünetekkel járó húgyúti fertőzés). Mivel a $K$. pneumoniae természetes rezisztenciával bír ampicillinnel szemben, a 2005-ben észlelt 88\%-os rezisztenciaarány tévesnek tekintendő.

\section{Következtetés}

Mivel a kórokozók helyi spektruma és antibiotikumokkal szembeni rezisztenciája idóben és földrajzi régiónként eltér, a helyi viszonyok felmérése rendkívül fontos, hogy megfelelő empirikus antibiotikum-kezelésben részesítsük a húgyúti fertőzésben szenvedő betegeket. A helyi rezisztenciaviszonyok ismerete megalapozza a megfeleló infekciókontroll és antibiotikum-kezelési stratégia felállítását. Kevésbé súlyos húgyúti fertőzések esetén szükségszerú a fluorokinolonok és cefalosporinok alkalmazásának visszaszorítása, illetve a helyi rezisztenciaviszonyok ismerete alapján, szúkebb spektrumú antibiotikumokkal történő helyettesitése. 
6. TÁBLÁZAT: REZISZTENCIA SULFAMETHOXAZOLE/TRIMETHOPRIM, NITROFURANTOIN, POLIMIXIN B ÉS FOSFOMYCIN ANTIBIOTIKUMOKKAL SZEMBEN: A LEGGYAKORIBB KÓROKOZÓK SULFAMETHOXAZOLE/TRIMETHOPRIM, NITROFURANTOIN, POLIMIXIN B ÉS FOSFOMYCIN REZISZTENCIÁJA 2004 És 2017 KÖZÖTT

\begin{tabular}{|c|c|c|c|c|c|c|c|c|c|c|c|c|c|c|}
\hline \multicolumn{11}{|c|}{ Sulfamethoxazole/trimethoprim-rezisztencia } & \multicolumn{4}{|c|}{ Nitrofurantoin-rezisztencia } \\
\hline \multirow[t]{2}{*}{ Év } & \multicolumn{2}{|c|}{ E. coli } & \multicolumn{2}{|c|}{ E. faecalis } & \multicolumn{2}{|c|}{$\begin{array}{l}\text { K. pneumo- } \\
\text { niae }\end{array}$} & \multicolumn{2}{|c|}{ P. mirabilis } & \multicolumn{2}{|c|}{ E. coli } & \multicolumn{2}{|c|}{ E. faecalis } & \multicolumn{2}{|c|}{$\begin{array}{l}\text { K. pneumo- } \\
\text { niae }\end{array}$} \\
\hline & $\%$ & $(n / N)$ & $\%$ & $(n / N)$ & $\%$ & $(n / N)$ & $\%$ & $(n / N)$ & $\%$ & $(n / N)$ & $\%$ & $(\mathrm{n} / \mathrm{N})$ & $\%$ & $(\mathrm{n} / \mathrm{N})$ \\
\hline 2004 & 19 & (24/128) & 13 & (5/38) & 13 & $(3 / 23)$ & 20 & $(2 / 10)$ & 2 & $(3 / 129)$ & 0 & $(0 / 38)$ & \multicolumn{2}{|c|}{ N.M. } \\
\hline 2005 & 19 & (27/140) & 24 & $(10 / 42)$ & 15 & $(4 / 26)$ & 38 & (3/8) & 1 & $(1 / 140)$ & 5 & $(2 / 42)$ & \multicolumn{2}{|c|}{ N.M. } \\
\hline 2006 & 24 & $(28 / 115)$ & 29 & (10/35) & 8 & $(1 / 13)$ & 27 & (3/11) & 2 & $(2 / 115)$ & 0 & $(0 / 35)$ & \multicolumn{2}{|c|}{ N.M. } \\
\hline 2007 & 29 & $(24 / 82)$ & 32 & $(14 / 44)$ & 4 & $(1 / 28)$ & 29 & $(4 / 14)$ & 2 & $(2 / 82)$ & 2 & $(1 / 44)$ & \multicolumn{2}{|c|}{ N.M. } \\
\hline 2008 & 26 & (4V156) & 33 & $(22 / 66)$ & 21 & $(7 / 33)$ & 50 & $(2 / 4)$ & 1 & (1/153) & 0 & $(0 / 66)$ & 18 & (6/33) \\
\hline 2009 & 28 & (33/116) & 23 & $(11 / 47)$ & 6 & $(1 / 16)$ & 33 & $(4 / 12)$ & 2 & $(2 / 116)$ & 2 & $(1 / 45)$ & 47 & $(9 / 19)$ \\
\hline 2010 & 30 & (31/105) & \multicolumn{2}{|c|}{ N.M. } & 16 & $(3 / 19)$ & 33 & $(4 / 12)$ & 1 & $(1 / 106)$ & 0 & $(0 / 46)$ & 71 & (15/21) \\
\hline 2011 & 31 & $(32 / 102)$ & \multicolumn{2}{|c|}{ N.M. } & 22 & $(6 / 27)$ & 57 & $(4 / 7)$ & 0 & $(0 / 55)$ & 0 & $(0 / 18)$ & 31 & $(4 / 13)$ \\
\hline 2012 & 23 & $(23 / 102)$ & \multicolumn{2}{|c|}{ N.M. } & 63 & $(19 / 30)$ & 63 & $(10 / 16)$ & 0 & $(0 / 65)$ & 0 & $(0 / 46)$ & 90 & $(18 / 20)$ \\
\hline 2013 & 19 & (18/95) & \multicolumn{2}{|c|}{ N.M. } & 28 & $(9 / 32)$ & 29 & $(4 / 14)$ & 1 & $(1 / 100)$ & 0 & $(0 / 81)$ & 91 & $(31 / 34)$ \\
\hline 2014 & 25 & (33/131) & \multicolumn{2}{|c|}{ N.M. } & 14 & $(6 / 42)$ & 33 & (7/21) & 0 & $(0 / 128)$ & 0 & $(0 / 89)$ & 100 & $(41 / 41)$ \\
\hline 2015 & 19 & $(22 / 118)$ & \multicolumn{2}{|c|}{ N.M. } & 36 & $(8 / 22)$ & 50 & $(8 / 16)$ & 0 & $(0 / 121)$ & 0 & $(0 / 70)$ & 100 & $(21 / 21)$ \\
\hline 2016 & 32 & $(42 / 132)$ & \multicolumn{2}{|c|}{ N.M. } & 49 & $(24 / 49)$ & 24 & $(4 / 17)$ & 0 & $(0 / 131)$ & 1 & $(1 / 103)$ & 100 & $(48 / 48)$ \\
\hline 2017 & 27 & $(34 / 127)$ & \multicolumn{2}{|c|}{ N.M. } & 44 & $(16 / 36)$ & 47 & (9/19) & 0 & $(0 / 128)$ & 0 & $(0 / 79)$ & 100 & (37/37) \\
\hline \multicolumn{9}{|c|}{ Polimixin B-rezisztencia } & \multicolumn{6}{|c|}{ Fosfomycin-rezisztencia } \\
\hline \multirow[t]{2}{*}{ Év } & & coli & \multicolumn{2}{|c|}{$\begin{array}{l}\text { K. pneu- } \\
\text { moniae }\end{array}$} & \multicolumn{2}{|c|}{ P. aeruginosa } & \multicolumn{2}{|c|}{ P. mirabilis } & & & K. pr & umo- & P. $r$ & ilis \\
\hline & $\%$ & $(n / N)$ & $\%$ & $(n / N)$ & $\%$ & $(n / N)$ & $\%$ & $(n / N)$ & $\%$ & $(n / N)$ & $\%$ & $(n / N)$ & $\%$ & $(n / N)$ \\
\hline 2010 & 0 & $(0 / 107)$ & 0 & $(0 / 21)$ & 0 & $(0 / 16)$ & 100 & $(12 / 12)$ & 0 & $(0 / 102)$ & 15 & $(3 / 20)$ & 9 & $(1 / 11)$ \\
\hline 2011 & 0 & $(0 / 108)$ & 0 & $(0 / 27)$ & 0 & $(0 / 13)$ & 100 & $(8 / 8)$ & 0 & $(0 / 90)$ & 4 & $(1 / 23)$ & 14 & $(1 / 7)$ \\
\hline 2012 & 0 & $(0 / 75)$ & 0 & $(0 / 18)$ & 0 & $(0 / 12)$ & 100 & $(11 / 11)$ & 5 & $(1 / 20)$ & 0 & $(0 / 7)$ & 0 & $(0 / 4)$ \\
\hline 2013 & 0 & $(0 / 103)$ & 0 & $(0 / 34)$ & 0 & $(0 / 20)$ & 100 & $(15 / 15)$ & & & & & & \\
\hline 2014 & 0 & $(0 / 131)$ & 0 & $(0 / 41)$ & 0 & $(0 / 45)$ & 100 & $(21 / 21)$ & & & & & & h. \\
\hline 2015 & 0 & $(0 / 122)$ & 0 & $(0 / 22)$ & 0 & $(0 / 16)$ & 95 & $(19 / 20)$ & & & & & & И. \\
\hline 2016 & 0 & $(0 / 132)$ & 0 & $(0 / 49)$ & 0 & $(0 / 38)$ & 100 & $(17 / 17)$ & & & & & & И. \\
\hline 2017 & 0 & $(0 / 133)$ & 0 & $(0 / 37)$ & 0 & $(0 / 27)$ & 100 & $(19 / 19)$ & & & & & & V. \\
\hline
\end{tabular}

N.M. - nincs meghatározva

\section{Irodalom}

1. Wagenlehner FM, Naber KG. Treatment of bacterial urinary tract infections: presence and future. European urology 2006; 49(2): 235-44. https://doi.org/10.1016/j.eururo.2005.12.017

2. Cek M, Tandogdu Z, Naber $K$, et al. Antibiotic prophylaxis in urology departments, 2005-2010. European urology 2013; 63(2): 386-94. https://doi.org/10.1016/j.eururo.2012.09.038

3. Wagenlehner FM, Bartoletti R, Cek M, et al. Antibiotic stewardship: a call for action by the urologic community. European urology 2013; 64(3): 358-60. https://doi.org/10.1016/j.eururo.2013.05.044

4. Johansen TE, Cek M, Naber KG, et al. Hospital acquired urinary tract infections in urology departments: pathogens, susceptibility and use of antibiotics. Data from the PEP and PEAP-studies. International journal of antimicrobial agents. 2006; 28(Suppl 1): S91-107. https://doi. org/10.1016/j.jjantimicag.2006.05.005

5. Bonkat G PR BR, Bruyère F, et al. Urological Infections. In: EAU Guidelines London: European Association of Urology 2017; pp. 857-920.

6. Magyar A, Koves B, Nagy K, et al. Spectrum and antibiotic resistance of uropathogens between 2004 and 2015 in a tertiary care hospital in Hungary. Journal of medical microbiology 2017; 66(6): 788-97. https:// doi.org/10.1099/jmm.0.000498

7. CLSI. Performance Standards for Antimicrobial Susceptibility Testing.
Wayne, PA: Clinical and Laboratory Standards Institute; 2004. http://clsi. org/ [2016.03.14.].

8. EUCAST. EUCAST MIC Breakpoint Tables. Basel: European Committee on Antimicrobial Susceptibility Testing; 2011. www.eucast.org/ [2016.03.12].

9. Elhanan G, Sarhat M, Raz R. Empiric antibiotic treatment and the misuse of culture results and antibiotic sensitivities in patients with community-acquired bacteraemia due to urinary tract infection. The Journal of infection 1997; 35(3): 283-8. https://doi.org/10.1016/50163-4453(97)93194-7

10. Sauer PF, Bueschen AJ, Vasconez LO. Lymphedema of the penis and scrotum. Clinics in plastic surgery 1988; 15(3): 507-11.

11. Tandogdu Z, Cek M, Wagenlehner F, et al. Resistance patterns of nosocomial urinary tract infections in urology departments: 8-year results of the global prevalence of infections in urology study. World journal of urology 2014; 32(3): 791-801.

12. Centers for Disease C, Prevention. Guidance for control of infections with carbapenem-resistant or carbapenemase-producing Enterobacteriaceae in acute care facilities. MMWR Morbidity and mortality weekly report 2009; 58(10): 256-60.

13. McCusker ME, Harris AD, Perencevich E, Roghmann MC. Fluoroquinolone use and Clostridium difficile-associated diarrhea. Emerging infectious diseases 2003; 9(6): 730-3. https://doi.org/10.3201/eid0906.020385 